УДК 340.132

DOI https://doi.org/10.32837/pyuv.v0i5(34).638

\author{
М. В. Котенко \\ orcid.org/0000-0001-8046-6641 \\ кандидат юридичних наук, \\ доиент кафедри інтелектуальної власності \\ Інституту права \\ Київського національного університету імені Тараса Шевченка
}

\title{
СУЧАСНИЙ СТАН ТА ПЕРСПЕКТИВИ РОЗВИТКУ НАУКОВОГО ПІЗНАННЯ ІНТЕЛЕКТУ АЛЬНОЇ ВЛАСНОСТІ ЯК ЦІННІСНО-ПРАВОВОГО ФЕНОМЕНУ
}

Вступ. Наукове пізнання будь-якого феномену економіко-правової дійсності неможливе без проведення грунтовного аналізу існуючого стану доктринального пізнання та визначення перспектив його розвитку. Це стосується і предмету нашого наукового дослідження - інтелектуальної власності як ціннісно-правового феномену, уявлення і ідеї щодо якого мають історично зумовлений характер та відзначаються конкретним станом своєї наукової розробки на цей час. Інтелектуальна власність як особливий соціокультурний ціннісний феномен має надзвичайно велику історичну «спадщину» у вигляді різноманітних наукових уявлень періоду Античності, численних наукових праць Середньовіччя і доби Нового часу, новаторських концепцій і теорій, висунутих сучасними правознавцями, економістами та філософами. Історизм вивчення інтелектуальної власності загалом та її ціннісно-правових аспектів зокрема зумовлюється передусім такою невіддільною властивістю інтелектуальної власності, як спроможність акумулювати в собі специфіку суспільно-правової дійсності. Інтелектуальна власність за своєю природою та сутністю є динамічним явищем, яке змінюється під впливом розвитку та функціонування різноманітних сфер суспільного життя. Інтелектуальна власність є такою, що підпадає під вплив суспільних і державних процесів певної історичної епохи, внаслідок цього трансформується відповідно до актуальних суспільно-політичних та правових потреб і цінностей. Водночас і саме явище інтелектуальної власності впливає на інші економіко-правові явища і процеси, визначаючи їх трансформацію, зміну їх функціональної ролі на конкретному етапі життєдіяльності суспільства.

У сучасній юридичній науці представлене широке коло наукових, в тому числі і дисертаційних досліджень, присвячених теоретичним та методологічним проблемам інтелектуальної власності, їі правовому забезпеченню, питанням її охорони та захисту, критичному аналізу переваг та недоліків практики забезпечення інтелектуальної власності в сучасних умовах розбудови держави і правової системи, логічним i понятійно-категоріальним засадам інтелектуальної власності тощо. Проте, попри те, що науковці приділяють значну увагу пізнанню інтелектуальної власності, питанням іï розуміння, функціонального призначення, правового забезпечення тощо, слід відзначити, що особливості стану іï доктринальної розробки та перспектив подальшого наукового пізнання є найменш дослідженими.

Безсумнівним є той факт, що з метою проведення результативного наукового дослідження та аналізу сучасних наукових уявлень про інтелектуальну власність, її вимір як ціннісно-правового феномену необхідно перш за все дослідити історичний «фундамент» вивчення інтелектуальної власності, визначити передумови, зміст і особливості зародження й становлення уявлень про інтелектуальну власність, з'ясувати можливі критерії періодизації розвитку цих уявлень та обгрунтувати саму періодизацію, дати характеристику кожному періоду розвитку даних уявлень, i, врешті решт, на основі опрацювання відповідної джерельної бази з'ясувати сучасний стан і перспективи наукового дослідження інтелектуальної власності як ціннісно-правового феномену. У наших власних публікаціях ми вже звертали увагу на те, що дослідження будь-яких явищ і процесів сучасної правової дійсності потребує насамперед визначення методологічної основи такого дослідження, встановлення переваг положень конкретного типу правопізнання. Аналіз положень типів правопізнання дозволив в результаті дійти висновку про переваги ціннісно-правового підходу до дослідження інтелектуальної власності як явища правової дійсності [1, с. 324]. Враховуючи зазначене, слід наголосити на тому, що проблематика інтелектуальної власності як об’єкту наукового пізнання буде розкрита нами в роботі крізь призму її розуміння як ціннісно-правового феномену, що акумулює в собі соціокультурні цінності сучасного суспільства та являє собою об’єкт правової охорони.

Мета та завдання дослідження. Відзначаючи високий рівень актуальності теми цієї наукової роботи, наголошуючи на доцільності посилення вивчення сучасного стану наукового дослідження 
інтелектуальної власності як ціннісно-правового феномену, відзначаючи методологічну важливість отриманих результатів такого дослідження, що дозволить з'ясувати сучасний стан іiї наукової розробки та охарактеризувати перспективні напрями подальшого наукового дослідження, вважаємо за доцільне метою цієї роботи визначити посилення пізнавальної основи вивчення ціннісно-правових аспектів інтелектуальної власності в сучасних умовах трансформації суспільства, держави та права. Досягнення поставленої мети нами пов'язується 3 виконанням наступних завдань: а) визначити особливості та узагальнити стан наукового дослідження інтелектуальної власності як ціннісно-правового феномену; б) встановити перспективні напрями наукового дослідження ціннісно-правових аспектів інтелектуальної власності.

Основна частина. Інтелектуальна власність явище складне і багатоаспектне, яке об’єктивно виникає з появою людства, оскільки є проявом людської розумової діяльності. Інтелектуальна власність є невіддільним чинником існування та розвитку сучасного суспільства, без інтелектуальної власності неможливо уявити будь-яке сучасне суспільство, вона є основою його розвитку та цивілізованості. Зазначене визначає високий пізнавальний рівень інтелектуальної власності, що знаходить свій прояв у численних наукових працях як вітчизняних, так і зарубіжних вчених. Сьогодні наукові дослідження інтелектуальної власності як правового явища представлені широким колом науковців - представників історико-теоретичних, галузевих та спеціальних юридичних наук. Вважаємо за доцільне їх узагальнити відповідно до виокремлених нами критеріїв. В залежності від предмету наукового дослідження окремі ціннісно-правові аспекти інтелектуальної власності розкрито в межах:

- історико-правових досліджень, де інтелектуальна власність досліджується як історично зумовлене явище правової реальності, що визначається закономірностями зародження, виникнення, становлення та розвитку. Відповідно, інтелектуальна власність розкривається вченими крізь призму історії становлення її правового забезпечення [2];

- порівняльно-правових досліджень, змістом яких є вивчення різноманітних правових аспектів інтелектуальної власності крізь призму її відмежування від інших суміжних явищ (категорій) юридичної науки, визначення їх спільних і відмінних ознак, особливостей їх взаємодії (взаємовпливу). Так, вченими розкриваються порівняльно-правові аспекти конституційно-правового захисту інтелектуальної власності зарубіжних країн [3];

- категоріальних досліджень, в яких вивчаються питання місця інтелектуальної власності в системі понятійно-категоріального апарату юридичної науки, з'ясовуються її ознаки та надаються їі характеристики, удосконалюється визначення поняття «інтелектуальна власність» [4];

- системно-структурних досліджень, що стосуються вивчення питань місця інтелектуальної власності в системі явищ правової реальності, з'ясування взаємозв'язку між інтелектуальною власністю та іншими суміжними правовими явищами (наприклад, творча діяльність, авторське право тощо). Так, вченими зроблено спробу дослідити системні аспекти правового захисту інтелектуальної власності [5]; набуття та захисту майнових прав інтелектуальної власності в Україні [6];

- інституційно-правових досліджень, змістом яких є вивчення інтелектуальної власності як проявуїінінституційнихскладників(суб'єктів,їхправового статусу, системи прав інтелектуальної власності, процесу їх реалізації тощо), що відображають в тому числі і її ціннісно-правовий вимір [7];

- праксеологічних досліджень, що присвячені аналізу інтелектуальної власності як об'єкту правової охорони і захисту, вчинення юридично значимих дій, націлених на забезпечення непорушності прав суб'єктів права інтелектуальної власності. Так, у юридичній науці представлені праці вчених, в яких досліджуються питання теорії та практики співвідношення загального та індивідуального правового регулювання відносин у сфері інтелектуальної власності [8].

Вказаний нами критерій узагальнення напрямів дослідження інтелектуальної власності як ціннісно-правового феномену не має виключного характеру та може бути розширений і доповнений іншими. Так само буде розширена і характеристика напрямів дослідження інтелектуальної власності загалом та їі ціннісно-правових аспектів зокрема. Слід відзначити, що сучасний стан дослідження інтелектуальної власності як ціннісно-правового феномену можна охарактеризувати як такий, що представлений широким колом наукових досліджень як вітчизняних, так і зарубіжних вчених. Однак наявним є високий рівень хаотичності та непослідовності наукових досліджень інтелектуальної власності, як тих, що були проведені в минулому, так і тих, що відбуваються сьогодні. В результаті можливо констатувати факт існування не стільки комплексного підходу до вивчення інтелектуальної власності, скільки значної кількості авторських індивідуальних розробок тих або інших аспектів інтелектуальної власності. Вказане потребує виокремлення та впровадження в практику наукового дослідження конкретних пізнавальних підходів до розуміння інтелектуальної власності, що мають засновуватись на положеннях відповідних загальновизнаних типів правопізнання. На нашу думку, за основу такого дослідження варто взяти в тому 
числі і аксіологічний підхід, що функціонально спроможний сформувати концептуальну пізнавальну стратегію дослідження інтелектуальної власності крізь призму їі ціннісно-правового сприйняття.

3 огляду на вказане вище вважаємо за доцільне окремо звернути увагу на перспективи наукового дослідження ціннісно-правових аспектів інтелектуальної власності, враховуючи особливості сучасного стану їх наукового дослідження. До таких перспектив можливо віднести наступні:

- по-перше, подальше наукове дослідження ціннісно-правових аспектів інтелектуальної власності потребує насамперед подолання пануючого в юридичній науці вузького інструментального підходу до розуміння інтелектуальної власності (як засобу забезпечення реалізації інтересів її суб’єктів. - Прим. авт.) та переходу до широкого її розуміння як складного та багатоаспектного явища, що є, з одного боку, самостійною сферою людської діяльності, а з іншого - результатом людської розумової діяльності, становить основу розвитку людства, забезпечує реалізацію інтелектуального потенціалу кожної людини. Відповідно, слід посилити вивчення теоретико-правових та практичних аспектів функціонування інтелектуальної власності крізь призму її широкого розуміння не лише як засобу забезпечення реалізації інтересів її суб'єктів, а саме як багатоаспектного явища, що є невіддільним елементом системи сучасних соціокультурних цінностей;

- по-друге, здійснення наукового дослідження ціннісно-правових аспектів інтелектуальної власності потребує подолання заідеологізованості представлених у юридичній науці поглядів на явище інтелектуальної власності, що сформувалися в радянській юридичній науці та в подальшому впливають на сучасні наукові дослідження інтелектуальної власності як правового явища, що зумовлено сприйняттям інтелектуальної власності переважно як результату виконання трудових обов'язків або складника загального суспільного прогресу;

- по-третє, наукове дослідження інтелектуальної власності крізь призму аксіологічного підходу до правопізнання потребує посилення світоглядного (філософського) осмислення феномену інтелектуальної власності, особливо в частині узагальнення переваг положень типів праворозуміння, недопущення їх суперечності, що має стати основою для узагальнення правового виміру інтелектуальної власності як пізнавального явища, дозволить окреслити його пізнавальні межі, відмежувати його від інших суміжних явищ правової дійсності;

- по-четверте, подальші наукові дослідження інтелектуальної власності як ціннісно-правового феномену мають розвиватись крізь призму поси- лення міждисциплінарності наукового пізнання, що має бути засновано на грунтовних дослідженнях теоретико-правових та практичних аспектів інтелектуальної власності. Таке акцентування на міждисциплінарності наукового пізнання інтелектуальної власності потенційно спроможне буде посилити методологічну основу подальших досліджень вказаної проблематики у межах як галузевих, так і спеціально-прикладних юридичних наук;

- по-п'яте, набувають виключної актуальності поєднання теоретико-правових і прикладних наукових досліджень інтелектуальної власності, що сприятиме, з одного боку, створенню належної емпіричної основи наукового дослідження, а 3 іншого боку - виробленню конкретних методичних пропозицій і рекомендацій у частині посилення правового забезпечення прав суб'єктів інтелектуальної власності, забезпечення його відповідності міжнародним системам охорони та захисту інтелектуальної власності.

Висновки. 3 огляду на складність та багатоаспектність інтелектуальної власності, принциповість аксіологічного підходу до вивчення ії теоретико-правових та практичних аспектів слід відзначити, що в ретроспективному плані інтелектуальна власність може бути досліджена не лише крізь призму історії зародження та розвитку її наукового юридичного пізнання, але і історії становлення та сучасного стану iï правового забезпечення. Тому як перспективний напрям дослідження тематики цієї наукової роботи варто визначити вивчення історії становлення та сучасного стану правового забезпечення інтелектуальної власності в Україні.

\section{Jimepamypa}

1. Котенко М.В. Ціннісно-правові аспекти розуміння інтелектуальної власності як основа моніторингу їі правового забезпечення. Альланах права: Правовий моніторинг і правова експертиза: питання теорї та практики. 2019. Вип. 10. С. 319-325.

2. Довгань Г.В. Становлення та розвиток законодавства України про інтелектуальну власність (історико-правовий аспект) : дис. ... канд. юрид. наук : 12.00.01. Л., 2009. 216 c.

3. Усов Г.В. Конституционно-правовая защита интеллектуальной собственности в России и зарубежных странах : сравнительно-правовое исследование : дис. ... канд. юрид. наук : 12.00.02. Москва, 2015. 188 c.

4. Верхолётов М.А. Интеллектуальная собственность как теоретико-правовая категория : дис. ... канд. юрид. наук : 12.00.01. Москва, 2005. $167 \mathrm{c.}$

5. Маркова О.В. Система правовой защиты интеллектуальной собственности : теоретико-институциональное исследование : дис. ... канд. юрид. наук : 12.00.01. Москва, 2012. 169 с.

6. Якубівський I.Є. Набуття та захист майнових прав інтелектуальної власності в Україні : монографія. Львів : ЛНУ імені Івана Франка, 2018. 522 с.

7. Дроб'язко В.С., Дроб'язко Р.В. Право інтелектуальної власності. Київ : Юрінком Інтер, 2004. 260 с. 
8. Орлова В.В. Теория и практика индивидуализации в сфере интеллектуальной собственности дис. ... д-ра юрид. наук : 12.00.03 Москва, 2005. 377 с.

\section{Анотація}

Котенко М. В. Сучасний стан та перспективи розвитку наукового пізнання інтелектуальної власності як ціннісно-правового феномену. - Стаття.

Наукове пізнання будь-якого феномену економіко-правової дійсності неможливе без проведення грунтовного аналізу існуючого стану доктринального пізнання та визначення перспектив його розвитку. Це стосується і предмету нашого наукового дослідження, уявлення і ідеї щодо якого мають історично зумовлений характер та відзначаються конкретним станом своєї наукової розробки на цей час. Інтелектуальна власність як особливий соціокультурний ціннісний феномен має надзвичайно велику історичну «спадщину» у вигляді різноманітних наукових уявлень періоду Античності, численних наукових праць Середньовіччя і доби Нового часу, новаторських концепцій і теорій, висунутих сучасними правознавцями, економістами та філософами. Історизм вивчення інтелектуальної власності загалом та її ціннісно-правових аспектів зокрема зумовлюється передусім такою невіддільною властивістю інтелектуальної власності, як її спроможність акумулювати в собі специфіку суспільно-правової дійсності.

У роботі автором відзначено доцільність посилення пізнавальної основи ціннісно-правових аспектів інтелектуальної власності в сучасних умовах трансформації суспільства, держави та права. На підставі аналізу наукових праць вітчизняних та зарубіжних вчених автором визначено особливості та узагальнено стан наукового дослідження інтелектуальної власності як ціннісно-правового феномену. Відзначено, що сучасний стан дослідження інтелектуальної власності як ціннісно-правового феномену можна охарактеризувати як такий, що представлений широким колом наукових досліджень як вітчизняних, так і зарубіжних вчених. Однак наголошено на високому рівні хаотичності та непослідовності наукових досліджень інтелектуальної власності, як тих, що були проведені в минулому, так і тих, що відбуваються сьогодні.

У підсумку автором встановлено та обгрунтовано перспективні напрями наукового дослідження ціннісно-правових аспектів інтелектуальної власності.
Ключові слова: власність, інтелектуальна власність, право інтелектуальної власності, правова цінність, аксіологічний методологічний підхід.

\section{Summary}

Kotenko M. V. Current state and prospects of development of scientific knowledge of intellectual property as a value-legal phenomenon. - Article.

Scientific knowledge of any phenomenon of economic and legal reality is impossible without a thorough analysis of the existing state of doctrinal knowledge and determine the prospects for its development. This also applies to the subject of our scientific research, ideas and ideas about which are historically determined and marked by the specific state of their scientific development today. Intellectual property as a special socio-cultural value phenomenon has an extremely large historical "heritage" in the form of various scientific ideas of antiquity, numerous scientific works of the Middle Ages and modern times, innovative concepts and theories put forward by modern jurists, economists and philosophers. The historicism of the study of intellectual property in general and its value and legal aspects, in particular, is due primarily to such an integral property of intellectual property as its ability to accumulate the specifics of social and legal reality.

The author notes the expediency of strengthening the cognitive basis of value and legal aspects of intellectual property in modern conditions of transformation of society, state and law. Based on the analysis of scientific works of domestic and foreign scientists, the author identifies the features and summarizes the state of scientific research of intellectual property as a value-legal phenomenon. It is noted that the current state of research of intellectual property as a value-legal phenomenon can be characterized as one that is represented by a wide range of scientific research of both domestic and foreign scientists. However, the high level of chaos and inconsistency of intellectual property research, both in the past and in the present, is emphasized.

As a result, the author identified and substantiated promising areas of research on the value and legal aspects of intellectual property.

Keywords: property, intellectual property, intellectual property law, legal value, axiological methodological approach. 